\title{
O PEWNYCH PROCESACH SLOWOTWÓRCZYCH W OBRĘBIE UKRAIŃSKICH OFICJALNYCH NAZW GRZYBÓW MAKROSKOPIJNYCH
}

\author{
PRZEMYSŁAW JÓŹWIKIEWICZ \\ Uniwersytet Wrocławski, Wrocław - Polska \\ przemyslaw.jozwikiewicz@uwr.edu.pl; ORCID: 0000-0002-3654-7724 \\ ПРО ДЕЯКІ СЛОВОТВІРНІ ПРОЦЕСИ У СФЕРІ \\ УКРАЇНСЬКИХ ОФІЦІЙНИХ НАЗВ МАКРОСКОПІЧНИХ ГРИБІВ \\ ПШЕМИСЛАВ ЮЗВІКЕВИЧ \\ Вроцлавський університет, Вроцлав - Польща
}

АНОТАЦІЯ. У статті висвітлено результати дослідження українських назв макроскопічних грибів, яке було проведене 3 урахуванням їхніх дериваційних ознак. Проаналізовано словотвірні процеси, які відбуваються у сфері мікологічної терміносистеми, описано творення назв грибів, що виникли в ході словотвірної деривації, композитів, юкстапозитів тощо.

Ключові слова: словотвірні процеси, офіційні українські назви, макроскопічний гриб, мікологічна терміносистема, деривація, словоскладання.

\section{ON CERTAIN WORD-FORMATION PROCESSES IN THE SPHERE OF OFFICIAL UKRAINIAN NAMES OF MACROFUNGI}

\section{PRZEMYSŁAW JÓŹWIKIEWICZ \\ University of Wroclaw, Wroclaw - Poland}

ABSTRACT. The article presents the results of an analysis of the Ukrainian names of macrofungi. The study was carried out with the focus on their derivative features. The author of the article describes the derivative processes occurring in the sphere of the mycological terminology, he analyzes the names derived from a proper derivation, as well as those resulting from adaptation, composition, etc.

Key words: word-formation process, official Ukrainian names, macrofungi, mycological terminology, derivation, composition.

$\mathrm{G}$ rzyby makroskopijne (ukr. макроскопічні гриби, макроміцети: makros (gr.) - duży, mykes (gr.) — grzyb, a także капелюшні гриби, иапинкові грибu) to nazwa odnosząca się do organizmów, których cechą charakterystyczną jest zauważalny gołym okiem owocnik. Jego rozmiar (nie zaś pokrewieństwo ewolucyjne) jest podstawowym kryterium decydującym o zaliczeniu danego gatunku do tej sztucznej i umownie utworzonej grupy grzybów. Jedynie grzyby workowe (аскомікотові гриби) i podstawkowe (базидієві гриби) współtworzące podkrólestwo Dikarya spełniają warunek odpowiedniej wielkości owocnika.

Według mykologów, na świecie może istnieć nawet do dwóch milionów gatunków grzybów, z których opisano zaledwie ok. 100 tys., a grzyby makroskopijne stanowią niewielki odsetek tej liczby. Szacuje się, że w Europie Środkowej i Wschodniej (w tym także na Ukrainie) występuje ok. 4-5 tys. gatunków grzybów wielkoowocnikowych, z czego tylko kilkadziesiąt ma znaczące zastosowanie użytkowe, 
przede wszystkim w przemyśle spożywczym i w medycynie. To właśnie nazwy grzybów opisywanych w atlasach, na stronach internetowych poświęconych grzybom i grzybiarstwu ${ }^{1}, \mathrm{w}$ przewodnikach stanowiły podstawę materiałową dla analiz z zakresu słowotwórstwa (derywacji właściwej, ale także adaptacji czy kompozycji) przedstawionych w niniejszym artykule.

Zarówno polska, ukraińska, jak i światowa literatura mykologiczna jest niezwykle obszerna i dotyczy wielu aspektów związanych z występowaniem, użytkowaniem i biologią grzybów ${ }^{2}$. Diametralnie inaczej rysuje się kwestia opracowań z zakresu słownictwa mykologicznego, tak dla obszaru języka polskiego, jak i ukraińskiego. Wprawdzie wśród polskich i ukraińskich uczonych wskazać można grupę badaczy (m.in. Barbara Bartnicka-Dąbkowska, Ewa Referowska-Chodak, Kazimierz Kopczyński, Maria Ławrynowicz, Ludmyła Symonenko, Maryna Tkaczuk, Rusłana Omelkoweć czy Zwenysława Kałyneć-Mamczur), którzy zajęli się problematyką nazewnictwa grzybów makroskopijnych, jednak badania te ograniczone są w zasadzie do tematyki etymologii nazw, ich funkcjonowania w dialektach i pewnych regionach geograficznych; niemal brak prac z zakresu terminologii czy derywatologii ${ }^{3}$.

Celem artykułu jest analiza nazw ukraińskich grzybów makroskopijnych pod kątem ich cech derywacyjnych i określenie struktury derywatów w poddanej badaniu próbce.

Poruszany temat jest ze wszech miar aktualny z uwagi na powszechność, a zarazem niemal zupełne nieopracowanie badanych kwestii, natomiast proponowane ujęcie problemu opierające się na wskazanej podstawie materiałowej to pierwsze tego typu omówienie w ukrainistyce od lat ${ }^{4}$.

Gatunkowe nazwy grzybów to zwykle struktury dwuelementowe. Taki właśnie model nazewniczy stosowany jest zarówno w przypadku łacińskich nazw grzybów, jak i nazw w językach nowożytnych. Skupienia imienne (głównie atrybutywne), na które składa się człon rodzajowy i epitet gatunkowy, będące odzwierciedleniem

${ }^{1}$ Bazę materiałową dla analiz słowotwórczych stanowiły nazwy wyekscerpowane z następujących źródeł: М. М. Сухомл ин, В. В. Джаган, Гриби Украӥни, Київ 2013; 3. Кал и не ц - Мам чур, Словник-довідник з альгології та мікологї̈, Львів 2011; Електронні ресурси: http://gribi.net.ua; http://www.cybertruffle.org.uk/ukrafung/ukr/index.htm; http://ua.griby.org.ua/naibilsh-poshyreni-gryby/; http://old.geology.lnu.edu.ua/phis_geo/fourman/Grybus\%20in\%20the\%20our\%20forests/mushr.htm (12.02.2018).

${ }^{2}$ Wykaz prac z tej dziedziny: zob. P. Jóźwikiewicz, Z problematyki nazewnictwa grzybów wielkoowocnikowych w języku ukraińskim i polskim — przegląd źródet, [w:] „Slavica Wratislaviensia”, CLXV, Wrocław 2017, s. 169-178.

${ }^{3}$ B. Bartnicka-Dąbkowska, Polskie ludowe nazwy grzybów, Prace językoznawcze PAN, Wrocław-Warszawa-Kraków 1964; A. Chlebicki, Zawiłości etymologiczne i znaczeniowe nazw „,huba” i ,hubka”, [w:] „Wiadomości Botaniczne”, Kraków 2010, 54 (1/2), s. 35-39; K. Ko p c zy ński, M. Ław ry nowicz, Polskie regionalne nazwy grzybów, [w:] M. Lisiewska, M. Ławrynowicz (red.), Monitoring grzybów, Poznań- Łódź 2000, s. 133-142; J. Ku źmi iu k, Nazwy niektórych grzybów w gwarach między Bugiem a Narwia, [w:] Badania dialektów i onomastyki na pograniczu polskowschodniostowiańskim, Białystok 1995, s. 137; E. Re ferow sk a-Chodak, Ludowe nazwy grzybów w Polsce, [w:] „Studia i materiały CEPL w Rogowie”, 2015, zeszyt 44 (3), s. 218-238; 3. Ка л и не ц М ам ч ур, Словник-довідник з альгології та мікології, Львів 2011; В. М. Кур и лен ко, Гриби губи: полісемія чи омонімія? (на матеріалі лексики поліських говорів), [в:] „Записки з українського мовознавства", Одеса 2006, вип. 16, с. 219-223; Р. О мель ко вець, Семантична трансформація як спосіб номінаиії мікооб'єктів у західнополіських говірках, [в:] „Типологія та функції мовних одиниць”, № 1, Луцьк 2014, с. 231-239; Л. О. С имонен ко, Синонімічні назви грибів в українській мові, [в:] „Рідне слово”, Київ 1973, вип. 7, с. 23-26; Л. О. Симоненко, Як назвати гриби?, [в:] „Рідне слово”, Київ 1974, вип. 9, с. 38-41; М. Ткачук, Мікономінація в чорнобильських говірках (питання реконструкиії ареалу), [в:] „Волинь - Житомирщина”, 2010, № 22 (2), c. 275-282.

${ }^{4}$ Zob. prace L. Symonenko, przede wszystkim Л. О. С и м онен но, Мікологічна лексика української мови: дис. ... канд. філол. наук, Київ 1973. 
upowszechnionego w XVIII w. nazewnictwa binominalnego, również i w ukraińskim systemie nazewnictwa grzybów są modelem wiodącym. Struktura nazw oficjalnych grzybów makroskopijnych w języku ukraińskim w dużym stopniu opiera się na źródłosłowach łacińskich (rzadziej greckich), jednakże elementy rdzennie ukraińskie są również obecne. Postać tych leksemów, ich budowa i miejsce w całym systemie nazw grzybów postrzeganych przez pryzmat procesów derywacyjnych jest zagadnieniem niezwykle interesującym i wartym przeanalizowania.

Aby dokonać analizy słowotwórczej nazw grzybów, weryfikacji poddano 1686 oficjalnych nazw gatunkowych grzybów wielkoowocnikowych występujących na Ukrainie.

Większość oficjalnych ukraińskich nazw grzybów składających się na analizowaną próbkę to skupienia terminologiczne bazujące na hipotaksie ${ }^{5}$ : model (N+Adj), np. Зморшок високий, rzadziej (Adj+N), np. Польський гриб. Prześledzić należy zatem, jak kształtuje się kwestia motywacji leksemów: członów konstytutywnych i akcesorycznych współtworzących atrybutywne skupienia proste.

1265 nazw $(75 \%)$ w analizowanej próbce to struktury, których człon rodzajowy (pierwszy element nazwy, z reguły rzeczownik) wywodzi się bezpośrednio z języków klasycznych (głównie łaciny, np. Геріцій коралоподібний, Кліточелла гірка, Постія птихогастер i in.). Wśród pozostałych 423 nazw grzybów, a dokładnie pośród ich członów rodzajowych, dominują leksemy stricte ukraińskie (niemal 400 przykładów, np. Рижик червоний, Вовнянка рожева i in.). Uwagę zwracają neosemantyzmy (Губка дубова, Келишок смугастий i in.), sporadycznie notowane leksemy niemotywowane (гриб, глива), jednak większość nazw jest rezultatem standardowych zabiegów derywacyjnych. Choć ukraińskie nazwy rodzajowe grzybów powstały głównie w wyniku sufiksacji, to w badanej próbce obecne są również leksemy uformowane przy użyciu cyrkumfiksów oraz kompozita.

Wachlarz sufiksów stosowanych w procesie tworzenia oficjalnych ukraińskich nazw rodzajowych grzybów nie jest stosunkowo szeroki. Najbardziej produktywny (11 typów ${ }^{6}$ członów rodzajowych) jest sufiks -овик (-евик), np. боровик, грабовик, дубовик, зірковик i in. Mniej liczne są nazwy powstałe przy użyciu sufiksów -к(a) (nр. вовнянка, поганка, розщепка), -ник (nр. павутинник, часничник), -ок (np. зморшок, строчок) сzу -ак (-як) (nр. гірчак, козляк, синяк). W kategoriach wyjątku należy rozpatrywać nazwy z wykładnikami -ач (np. головач), -ик (np. puжик, рогатик), -иц(я) (-ниц(я) (nр. лаковиия, тарілочничя, печіночниия), -ух (а) (np. мокруха, свинуха) czy -юк (np. маслюк). Wiele z tych nazw (np. боровик, вовнянка, маслюк i in.) ma pochodzenie prasłowiańskie, na co wskazuje ich obecność we współczesnych językach słowiańskich?

Bazą dla wymienionych derywatów były przede wszystkim rzeczowniki, (np. головач $\leftarrow$ голова, павутинник $\leftarrow$ павутина, моховик $\leftarrow$ мох, моховичок $\leftarrow$ моховик), rzadziej przymiotniki (np. гірчак $\leftarrow$ гіркий, поганка $\leftarrow$ поганий, мокруха $\leftarrow$ мокрий) czy czasowniki (np. розщепка $\leftarrow$ розщепити).

Nie można zapominać również o nazwach, których etymologia nie jest do końca wyjaśniona. Takim leksemem jest choćby печериия. Nazwa powstała przy zastoso-

\footnotetext{
${ }^{5}$ Niektórzy językoznawcy, np. Alicja Nagórko, wskazują, iż są to zestawienia niewspółrzędne z określnikiem przymiotnikowym. Zob. A. N a gó rk o, Zarys gramatyki polskiej, Warszawa 2000, s. 198.

${ }^{6} 11$ typów członów rodzajowych to 100 przykładów nazw w próbce; np. człon rodzajowy sipковик to element bazowy szesnastu nazw (np. Зірковик маленький, Зірковик гребінчастий, Зірковик рудіючий i in.).

${ }^{7}$ I. В. С а бадош, Як звуться гриби?, [в:] Електронний pecypc: http://kulturamovy.univ.kiev. ua/KM/pdfs/Magazine34-10.pdf (12.02.2018).
} 
waniu sufiksu -иц(я), jednak element motywujący budzi wątpliwości badaczy (neкти, печера lub печеня турова ${ }^{8}$.

W badanym materiale w zasadzie brak leksemów, które powstałyby li tylko $\mathrm{w}$ rezultacie prefiksacji. Wyjątkiem są konstrukcje $\mathrm{z}$ greckim komponentem псевдо-, który, jak zauważa Iryna Koczan ${ }^{9}$, nie wchodzi dość często w skład struktur z elementami rodzimymi (Псевдолійочник хвилястий, Псевдоӥжовик драглистий, Псевдорядовка блідо-червонувата і in.).

Do relatywnie produktywnych formantów (zwłaszcza w obrębie ludowych nazw grzybów ${ }^{10}$ ) należą cyrkumfiksy, szczególnie zaś segmenty z elementem під-, np. підгруздок, підвишень, підвільшанник, підосичник, підберезник $\mathrm{i}$ in.

$\mathrm{Na}$ uwagę zasługują człony rodzajowe nazw grzybów zawierające co najmniej dwa morfemy rdzenne. Kompozyty są dość liczne. Ich obecność zanotowano w 159 skupieniach (9,4\% wszystkich nazw, aż 39,75\% wśród nazw stricte ukraińskich). Składają się na nie złożenia, np. білогнойовик, білопавутинник, білопечериця, мухомор, пилолистник, сироїжка, чорнопластинник, шишкогриб oraz zestawienia, nр. хрящ-молочник, гриб-зонтик, гриб-парасолька, гриб-баран.

W funkcji epitetów gatunkowych ukraińskich oficjalnych nazw grzybów występują głównie przymiotniki oraz imiesłowy przymiotnikowe ${ }^{11}$. Liczba i zróżnicowanie formantów obecnych w tym elemencie nazewniczym zdecydowanie przewyższa omawiane wyżej w kontekście derywacji człony rodzajowe.

Przymiotniki pełniące funkcje członów akcesorycznych skupień atrybutywnych powstały przy wykorzystaniu następujących sufiksów ${ }^{12}$ (834 przykłady, 49,9\%): -ав-: Ценангій іржавий, Фускопорія іржава; -аст-: Гельвела ямчаста, Феомаразмій голчастий, Телефора пальчаста, Кордіценс головчастий; -ат-: Скутелінія волосата, Томентелла волохата, Тріхопецицелла бородата, Тулостома луската; -ев- (-св-): Бруннеопор яблуневий, Опеньок тополевий, Дермея вишнева, Ентолома квітнева, Іночибе інієвий, Лепіота горностаєва; -еньк-: Ентолома шершавенька, Геміміцена тоненька, Гігроцибе гостренька, Іноцибе гладенький; -ечн-: Саркосфера вінечна; -ив-: Гнойовичок мерехтливий, Павутинник оманливий, Крепідот мінливий; -ин-: Моховик буйволиний; -ист-: Мухомор щзетинистий, Хейліменія зерниста, Мокруха плямиста, Гельвела ребриста;-івн-: Фоліота руйнівна, Сиройжка їстівна, Стробілюрус їстівний;-іш-: Павутинник красивіший; -к-: Глутиноглос клейкий; -н-: Клімакоцистис північний, Клітоиибе запашний, Павутинник дібровний, Галеропсис пустельний; -ов-: Крепідот моховий, Лахнум коровий, Свинуха вільхова, Пеніофора грабова; -ськ-: Польський гриб, Модринофомес лікарський, Скутелінія гірська, Менсуларія гірська; -уват-: Хрящ-молочник солодкуватий, Псевдоплектанія чорнувата, Ризопогон рожевуватий, Рядовка зморикувата; -ян-: Порхавка болотяна, Павутинник трав'яний, Павутинник весняний, Гігроиибе изегляна; -яч-: Павутинник козячий, Трюфель оленячий, Лепіота котяча.

${ }^{8}$ Етимологічний словник украӥнської мови, у 7 томах, ред. кол.: О. С. Мельничук (гол. ред.), Т. Б. Лукінова, В. Т. Коломієць, Г. П. Півторак, В. Г. Скляренко, О. Б. Ткаченко, Київ 2003, т. 4, с. 364.

9 I. М. Кочан, Українська наукова лексика. Міжнародні компоненти в термінологї̈, Київ 2013, с. 159-162.

10 Л. О. С имоненко, Синонімічні назви грибів в українській мові, [в:] „Рідне слово”, Київ 1973, вип. 7, с. 23-26.

${ }^{11}$ Zanotowano kilka przykładów, w których funkcję epitetu gatunkowego pełni rzeczownik, zob. nierównorzędne binomina.

${ }^{12} \mathrm{Z}$ uwagi na ograniczenia redakcyjne podano po cztery przykłady nazw dla każdego sufiksu, mniejsza liczba prezentowanych przykładów jest rzeczywista dla analizowanej próbki. 
$\mathrm{W}$ analizowanej próbce zanotowano również przymiotniki powstałe $\mathrm{w}$ wyniki prefiksacji ${ }^{13}$, choć pod względem różnorodności wykładników jest to grupa zdecydowanie mniej liczna (22 przykłady, 1,3\%): най-: Брефельдія найбільша, Хеймонофіллум найчистіший, Хрящ-молочник найгостріший, Тречіспора найбіліша; не-: Калорія непомітна, Гебелома недосяжна, Лисичка несправжня, Мерисмоде нечітка; пре-: Клімакодон прекрасний, Павутинник пречудовий, Гігрочибе прекрасна;

W funkcji epitetów gatunkowych oficjalnych nazw grzybów makroskopijnych występują także przymiotniki będące rezultatem zabiegów prefiksalno-sufiksalnych. W pozycji drugiego segmentu cyrkumfiksu najczęściej (14 przykładów, 0,8\%) występują elementy -н(ий), -ов(ий), -ев(ий), пр.: без-: Оннія безніжкова, Пізоліт безкореневий; на-: Біссонектрія наземна, Лікогала надеревна, Маразмій налистяний, Оссикауліс надеревинний; під-: Ентолома підвишнева; при-: Печериия прибережна, Павутинник придорожній, Моховичок прибережний; су-: Фускопорія суміжна.

Istotną grupę leksemów pełniących funkcję epitetów gatunkowych ukraińskich nazw grzybów stanowią imiesłowy przymiotnikowe. Ich obecność jest zauważalna (174 przykłady, 10,3\%), a stwierdzenie to dotyczy zarówno imiesłowów przymiotnikowych czynnych, jak i biernych. W analizowanym materiale występowały imiesłowy utworzone przy pomocy niemal wszystkich rodzajów wykładników imiesłowowych.

Imiesłowy przymiotnikowe aktywne (72 przykłady), nр.: -л-: Хрящ-молочник бляклий, Неолентин прирослий, Радуломічес зрослий, Тефрочибе почорнілий; -уч- (-юч-): Антродіелла повзуча, Порхавка пахуча, Порхавка чорніюча, Дакримічес зникаючий; -ач- (-яч-): Ірпікодон висячий, Флебія тремтяча.

Imiesłowy przymiotnikowe pasywne (102 przykłady), np.: -н- (-ан-, -ян-, -ен-, -ован-): Павутинник намазаний, Павутинник надрізаний, Гнойовичок розсіяний, Фелін вирівняний, Трутовик лакований, Трихоломелла перешнурована, Порхавка укорінена, Кудонія закручена; -т-: Клітоиибе увігнутий, Кокоміцес роздутий, Крепідот розгорнутий, Діанема притиснута.

Przytoczony materiał dowodzi szerokiej produktywności leksemów współtworzących oficjalne ukraińskie nazwy grzybów wielkoowocnikowych i właściwych procesów derywacyjnych zachodzących w ich obrębie.

Wprawdzie adaptacja to nie sensu stricto słowotwórstwo, jednak procesy asymilacyjne, do których dochodzi na płaszczyźnie języka, przystosowywanie elementów obcych do ukraińskiego systemu gramatycznego, są w przypadku słownictwa mykologicznego na tyle wyraźne, że należy o nich wspomnieć.

Jedynie 210 nazw grzybów, a więc nieco ponad 12\% nazw w próbce, to konstrukcje powstałe przy wykorzystaniu rodzimych ukraińskich elementów leksykalnych, a przy tym zupełnie nieodnoszące się do nazwy łacińskiej. Przynajmniej jeden element pozostałych $88 \%$ nazw bazuje na językach klasycznych - grece lub łacinie. Język ukraiński, podobnie jak inne języki słowiańskie, dysponuje bogactwem środków warunkujących asymilację obcych leksemów. Rezultatem adaptacji morfologicznej zapożyczeń są struktury hybrydalne. Ich obecność pośród analizowanych nazw grzybów makroskopijnych jest zauważalna (85 nazw, 5,1\% w próbce), choć dotyczy w zasadzie wyłącznie ${ }^{14}$ epitetów gatunkowych, a więc członu akceso-

${ }^{13}$ Zanotowano jeden przypadek użycia komponentu псевдо-, jednak wchodził on w skład przymiotnika złożonego (Скутелінія псевдошершавоспорова).

${ }^{14} \mathrm{~W}$ badanej próbce znalazły się dwie nazwy, w których pierwszy z elementów, a więc człon rodzajowy, jest hybrydą. Pierwszy z przykładów, Кальмарник веретеноподібний (кальмар-ник $\leftarrow$ кальмар), spełnia warunek pozwalający na zakwalifikowanie go do omawianej grupy, jednak greckołacińska nazwa grzyba (Pseudocolus fusiformis) nie stała się podstawą do bezpośredniego utworzenia 
rycznego skupienia atrybutywnego. Funkcję tę pełnią przede wszystkim przymiotniki powstałe $\mathrm{w}$ oparciu o obcą podstawę i ukraiński element asymilujący. Wśród ukraińskich cząstek ${ }^{15}$ biorących udział $\mathrm{w}$ procesie asymilacji zapożyczeń należy wymienić: -альн- (Cortinarius triumphans - Павутинник тріумфальний), -зьк(Athelia teutoburgensis - Ателія тевтобурзька), -ичн- (Astraeus hygrometricus - Aстрей гігрометричний, Asterophora parasitica - Acтерофора паразитична), -ев-/-св- (Russula pelargonia - Сироїжка пеларгонісва, Sclerotinia sclerotiorum Склеротинія склерочієва), -ов- (Botryohyросhnиs isabellinum - Ботріохіпохнус ізабелловий, Amanita porphyria - Мухомор порфировий), -н- (Peniophora incarnata - Пеніофора інкарнатна, Amanita pantherina - Мухомор пантерний), -ськ- (Calvatia gigantea - Головач гігантський, Coriolopsis gallica-Kоріолопсис гальський). Najliczniejsze w badanej próbce są hybrydy powstałe z wykorzystaniem elementów -oB- i -H- (54 przykłady, 3,2\%).

W swoistej opozycji do opartej na jednym temacie słowotwórczym derywacji prostej stoją kompozycje (w badanej próbce głównie kalki nazw łacińskich i greckołacińskich). Wśród 501 konstrukcji atrybutywnych (29,6\% w próbce), których człon akcesoryczny wyrażony jest przymiotnikiem złożonym obecne są złożenia niewspółrzędne i zestawienia.

Złożenia niewspółrzędne z nadrzędnikiem przymiotnikowym:

$\left(\mathbf{N}+\mathbf{A d j}_{1}\right) \mathbf{A d j}_{2}$ Agaricus amanitaeformis

Amanita ovoidea

Arrhenia auriscalpium

Arrhenia epichysium

$\left(\mathbf{A d v}+\mathbf{A d j}_{1}\right) \mathbf{A d j}_{2}$

Butyriboletus subappendiculatus

Hemileccinum impolitum

Cystolepiota seminuda

Печериия мухомороподібна ${ }^{16}$

Мухомор яйцеподібний

Арренія ложковидна

Арренія келиховидна ${ }^{17}$

Złożenia niewspółrzędne z nadrzędnikiem rzeczownikowym:

$\left(\operatorname{Adj}_{1}+\mathbf{N}\right) \operatorname{Adj}_{2}$

Fuligo leviderma

Galerina camerina

Inocybe calospora

Боровик напівпридатковий

Боровик напівбілий

Цистолепіота напівгола

$(\mathbf{N u m}+\mathbf{N})$ Adj

Geastrum quadrifidum

Gelatoporia dichroa

Фуліго гладкошкірий

Галерина випуклошапкова

Іночибе красивоспоровий ${ }^{18}$

Jackrogersella multiformis

Зірковик чотирипелюстковий

Желатопорія двоколірна

$\left(\mathbf{N}_{1}+\mathbf{N}_{2}\right)$ Adj

Dermoloma cuneifolium

Джекрожерселла багатолика

Дермолома клинолиста

struktury hybrydalnej. Z kolei nadrzędnik nazwy gatunkowej Порфировик червоноспоровий (Рогphyrellus porphyrosporus) mógł zostać utworzony przy wykorzystaniu cząstki -овик, jednakże o wiele bardziej przekonującą jest klasyczna ścieżka derywacyjna порфиров-ик $\leftarrow$ порфировий.

${ }^{15} \mathrm{O}$ cząstkach, sufiksach i quasi-sufiksach zob. m.in. A. Nagórko, Zarys gramatyki polskiej, Warszawa 2000, s. 190-191.

${ }^{16} \mathrm{~W}$ wielu pracach z morfemiki i słowotwórstwa element -подібний traktowany jest jako sufiksoid.

${ }^{17}$ Złożenia z elementem видний niekiedy mogą ulegać modyfikacjom poprzez dodanie kolejnego członu, np. przysłówka (prefiksoidu) напів- (Panaeolus semiovatus - Панеолус напівяйцевидний, Psilocybe semilanceata - Псилочибе напівланцетовидна).

${ }_{18} \mathrm{~W}$ analizowanej próbce znajduje się nazwa, której epitet gatunkowy składa się z trzech elementów - Гнойовик грубобородавчастоспоровий $\left(\operatorname{model}\left(\mathbf{A d j}_{\mathbf{1}}+\mathbf{A d j}_{\mathbf{2}}+\mathbf{N}\right) \mathbf{A d j}_{\mathbf{3}}\right)$. 
Leисосорrinus cepistipes Білогнойовик циибуленогий

Scutellinia crucipila Скутелінія хрестоволоскова

Złożenia niewspółrzędne z nadrzędnikiem czasownikowym:

$(\mathbf{A d v}+\mathbf{V})$ Adj

Botryobasidium subcoronatum

Cortinarius calochrous

Mycena diosma

$(\mathbf{N}+\mathbf{V})$ Adj

Eocronartium muscicola

Hypochnicium geogenium

Mycena sanguinolenta

Ботріобазидій майжеувінчаний

Павутинник красивозабарвлений

Мічена двоякопахуча

Еокронариій мохолюбивий

Гіпочніціум землеродний

Мічена кровоточива

Zestawienia przymiotnikowe to rodzaj kompozytów, który stanowi niemal 17\% wszystkich epitetów gatunkowych w obrębie badanej próbki (281 przykładów), np.:
Boletopsis leucomelaena Болетопсис біло-чорний
Chlorociboria aeruginosa Хлорочиборія синьо-зелена
Russula ochroleuca
Russula vinosa
Сироїжка охряно-жовта
Сироїжка винно-червона

Wśród przytoczonych juxtapozycji przeważają struktury dwuelementowe, jednak obecne są również konstrukcje bardziej złożone ${ }^{19}$, np.:
Clitocybe subalutacea
Клітоиибе світло-сіро-жовтий
Panellus violaceofulvus Панел фіолетово-буро-жовтий

Wyżej wspomniano o rzeczownikowych zestawieniach równorzędnych (typu хрящ-молочник), które występowały w funkcji członu rodzajowego analizowanych mykonimów. W badanym materiale obecne są również nierównorzędne binomina (składające się z dwóch rzeczowników) stanowiące kompletną nazwą grzyba, np.:
Gyromitra parma
Helvella monachella
Строчок щит
Hygrocybe cantharellus
Psilocybe inquilina
Гельвела монашка
Гігроиибе лисичка
Псилочибе мешканка

Przytaczane w niniejszym artykule przykłady to w znakomitej większości struktury złożone - skupienia terminologiczne, które, jak pisze Stanisław Gajda ${ }^{20}$, ale i inni uczeni ${ }^{21}$, stanowić mogą nawet do $90 \%$ zasobów większości systemów terminologicznych. Jednoelementowe nazwy grzybów występujące $\mathrm{w}$ analizowanym materiale są zjawiskiem marginalnym (9 leksemów, $0,53 \% \mathrm{~W}$ próbce, np. гірчак, підвишень, підвільшанник, синяк i in.), jednak również na ich bazie można było dokonać oglądu procesów słowotwórczych zachodzących w obrębie ogółu nazw wyekscerpowanych z wymienionych wyżej źródeł.

Gros członów rodzajowych to zapożyczenia o proweniencji łacińskiej, bądź grecko-łacińskiej. Jedynie $25 \%$ z nich stanowią leksemy stricte ukraińskie powstałe

\footnotetext{
${ }^{19} \mathrm{Na}$ marginesie rozważań derywacyjnych wypada nadmienić, że elementy epitetów gatunkowych oficjalnych nazw grzybów ulegają niekiedy duplikacji, np.: Павутинник каштановий слизький, Трюфель оленячий вугільний, Трутовик несправжній дубовий, Хрящ-молочник сірий ліловіючий, Лімацелла масляна червоніюча, Опеньок несправжній сірчано-жовтий, Опеньок несправжній цееляночервоний $\mathrm{i}$ in.

${ }^{20}$ S. Gaj da, Wprowadzenie do teorii terminu, Opole 1990, s. 96.

${ }^{21}$ M.in. Walentyna Bałoh, Zinajida Sikorśka, Daria Szapran, Ołena Kołhan, Jewhenija Jemeljanowa (zob. P. Jóźwikie wi cz, Słownictwo mykologiczne w języku ukraińskim i polskim - zarys problematyki, struktura terminów), [w:] „Studia Ucrainica Posnaniensia”, zeszyt V, Poznań 2017, s. 81-89).
} 
w wyniku zabiegów derywacyjnych — głównie sufiksacji (obecność prefiksów czy kompozytów jest śladowa). Odmiennie rysuje się sytuacja w obrębie epitetów gatunkowych. Zarówno różnorodność zabiegów słowotwórczych (derywacja właściwa, adaptacja, kompozycja), jak i wachlarz użytych środków wskazują tu na znaczną produktywność języka ukraińskiego. Choć zdecydowanie przeważa klasyczna sufiksacja (niemal tysiąc przykładów, $60 \% \mathrm{w}$ próbce), to jednak obecność hybryd (85 przykładów, 5\%), a w szczególności kompozytów różnego rodzaju (ponad 500 przykładów, $29,6 \%$ w próbce) jest zauważalna.

Podsumowując należy podkreślić, że struktura ukraińskich oficjalnych nazw grzybów makroskopijnych z punktu widzenia ich cech słowotwórczych jest niezwykle interesująca. $Z$ jednej strony bowiem świadczy o otwartości ukraińszczyzny na obce wpływy i asymilację odmiennych genetycznie leksemów, z drugiej zaś wskazuje na jej potencjał derywacyjny i możliwości (nie zawsze wykorzystywane) obsługiwania sfery terminologii naukowej.

\section{Wykaz wykorzystanej literatury}

Гриби та грибні місия, [в:] Електронний pecypc: http://ua.griby.org.ua/naibilshposhyrenigryby/ (15.02.2018).

Гриби України, [в:] Електронний ресурс: http://www.cybertruffle.org.uk/ukrafung/ukr/ index.htm (18.02.2018).

Етимологічний словник української мови, у 7 томах, ред. кол.: О. С. Мельничук (гол. ред.), Т. Б. Лукінова, В. Т. Коломієць, Г. П. Півторак, В. Г. Скляренко, О. Б. Ткаченко, Київ 2003, т. 4.

Калинець-Мамчур 3., Словник-довідник з альгології та мікології, Львів 2011.

Кочан І. М., Українська наукова лексика. Міжнародні компоненти в термінології, Київ 2013.

Куриленко В. М., Гриби - губи: полісемія чи омонімія? (на матеріалі лексики поліських говорів), [в:] „Записки з українського мовознавства”, Одеса 2006, вип. 16, с. 219-223.

Омельковець Р., Семантична трансформація як спосіб номінації мікооб'єктів y західнополіських говірках, [в:] „Типологія та функції мовних одиниць”, Луцьк 2014, № 1, c. 231-239.

Сабадош I. В., Як звуться гриби?, [в:] Електронний ресурс: http://kulturamovyuniv.kiev. ua/KM/pdfs/Magazine34-10.pdf (12.02.2018).

Світ грибів Украӥни, [в:] Електронний ресурс: http://gribi.net.ua (10.02.2018).

Симоненко Л. О., Мікологічна лексика української мови, дис. ... канд. філол. наук, Київ 1973.

Симоненко Л. О., Синонімічні назви грибів в украӥнській мові, [в:] „Рідне слово”, Київ 1973, вип. 7, с. 23-26.

Симоненко Л. О., Як назвати гриби?, [в:] „Рідне слово”, Київ 1974, вип. 9, с. 38-41.

Справжні гриби в наших лісах, [в:] Електронний pecypc: http://old.geology.lnu.edu.ua/ phis_geo/fourman/Grybus\%20in\%20the\%20our\%20forests/mushr.htm (11.02.2018).

Сухомлин М. М., Джаган В. В., Гриби України, Київ 2013.

Ткачук М., Мікономінація в чорнобильських говірках (питання реконструкиії ареалу), [в:] „Волинь - Житомирщина”, 2010, № 22 (2), с. 275-282.

Bartnicka-Dąbkowska B., Polskie ludowe nazwy grzybów, Prace językoznawcze PAN, Wrocław-Warszawa-Kraków 1964.

Chlebicki A., Zawiłości etymologiczne i znaczeniowe nazw ,huba” $i$,hubka”, [w:] „Wiadomości Botaniczne”, Kraków 2010, 54 (1/2), s. 35-39.

Gajda S., Wprowadzenie do teorii terminu, Opole 1990.

Jóźwikiewicz P., Słownictwo mykologiczne $w$ języku ukraińskim i polskim - zarys problematyki, struktura terminów), [w:] „Studia Ucrainica Posnaniensia”, zeszyt V, Poznań 2017, s. 81-89. 
Jóźwikiewicz P., Z problematyki nazewnictwa grzybów wielkoowocnikowych $w$ języku ukraińskim i polskim - przegląd źródeł, [w:] „Slavica Wratislaviensia”, CLXV, Wrocław 2017, s. 169-178.

Kopczyński K., Ławrynowicz M., Polskie regionalne nazwy grzybów, [w:] M. Lisiewska, M. Ławrynowicz (red.), Monitoring grzybów, Poznań-Łódź 2000, s. 133-142.

Kuźmiuk J., Nazwy niektórych grzybów w gwarach między Bugiem a Narwia, [w:] Badania dialektów i onomastyki na pograniczu polsko-wschodniosłowiańskim, Białystok 1995.

Nagórko A., Zarys gramatyki polskiej, Warszawa 2000.

Referowska-Chodak E., Ludowe nazwy grzybów w Polsce, [w:] „Studia i materiały CEPL w Rogowie", 2015, zeszyt 44 (3), s. 218-238.

\section{Wykaz wykorzystanej literatury [References]}

Hryby ta hrybni mistsya [Mushrooms and mushroom places], [in:] Elektronnyi resurs: http:// ua.griby.org.ua/naibilsh-poshyreni-gryby/ (15.02.2018).

Hryby Ukrayiny [Mushrooms of Ukraine], [in:] Elektronnyi resurs: http:/www.cybertruffle. org.uk/ukrafung/ukr/index.htm (18.02.2018).

Etymolohichnyy slovnyk ukrainskoyi movy [Etymological Dictionary of the Ukrainian Language], v 7 tomakh, red. kol.: O. S. Melnychuk (hol. red.), T. B. Lukinova, V. T. Kolomiyets, H. P. Pivtorak, V. H. Sklyarenko, O. B. Tkachenko, t. 4, Kyiv 2003.

Kalynets-Mamchur Z., Slovnyk-dovidnyk z alholohiyi ta mikolohiyi [Dictionary on Algology and Mycology], Lviv 2011.

Kochan I. M., Ukrayinska naukova leksyka. Mizhnarodni komponenty v terminolohiyi [Ukrainian Scientifi c Lexis. International Components in Terminology], Kyiv 2013.

Kurylenko V. M., Hryby — huby: polisemiya chy omonimiya? (na materiali leksyky poliskykh hovoriv) [Mushrooms - Lips: Polysemy or Homonymy?], [in:] „Zapysky z ukrainskoho movoznavstva", Odesa 2006, vyp. 16, s. 219-223.

Omelkovets R., Semantychna transformatsiya yak sposib nominatsiyi mikoobyektiv u zakhidnopoliskykh hovirkakh [Semantic Transformation as Means of Nomination of Mycoobjects in Western Polissya Dialects], [in:] „Typolohiya ta funktsiyi movnykh odynyts", № 1, Lutsk 2014, s. 231-239.

Sabadosh I. V., Yak zvutsya hryby? [What are the Names of Mushrooms?], [in:] Elektronnyi resurs: http://kulturamovy.univ.kiev.ua/KM/pdfs/Magazine34-10.pdf (12.02.2018).

Svit hrybiv Ukrayiny [The world of mushrooms], [в:] Електронний ресурс: http://gribi.net. ua (10.02.2018).

Symonenko L. O., Mikolohichna leksyka ukrainskoyi movy [Mycological Lexis in Ukrainian], dys. ... kand. filol. nauk, Kyiv 1973.

Symonenko L. O., Synonimichni nazvy hrybiv v ukrainskiy movi [Synonymic Names of Mushrooms in Ukrainian], [v:] „Ridne slovo”, Kyiv 1973, vyp. 7, s. 23-26.

Symonenko L. O., Yak nazvaty hryby? [How to Name Mushrooms?], [v:] „Ridne slovo”, Kyiv 1974, vyp. 9, s. 38-41.

Spravzhni hryby $v$ nashykh lisakh [True mushrooms in our forests], [in:] Elektronnyi resurs: http://old.geology.lnu.edu.ua/phis_geo/fourman/Grybus\%20in\%20the\%20our\%20 forests/mushr.htm (11.02.2018).

Sukhomlyn M. M., Dzhahan V. V., Hryby Ukrayiny [Mushrooms of Ukraine], Kyiv 2013.

Tkachuk M., Mikonominatsiya $v$ chornobylskykh hovirkakh (pytannya rekonstruktsiyi arealu) [Mining in the Chornobyl dialects (issues of the area's reconstruction)], [v:] „Volyn Zhytomyrshchyna”, 2010, № 22 (2), s. 275-282.

Bartnicka-Dąbkowska B., Polskie ludowe nazwy grzybów, Prace językoznawcze PAN, Wrocław-Warszawa-Kraków 1964.

Chlebicki A., Zawiłości etymologiczne i znaczeniowe nazw „huba” i ,hubka”, [w:] „Wiadomości Botaniczne”, Kraków 2010, 54 (1/2), s. 35-39.

Gajda S., Wprowadzenie do teorii terminu, Opole 1990. 